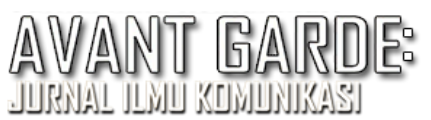

\title{
Representasi Patriotisme Pada Film Soegija (Analisis Semiotika John Fiske)
}

\author{
Nexen Alexandre Pinontoan \\ nexenalexandre@gmail.com \\ Program Studi Magister Ilmu Komunikasi, Universitas Budi Luhur \\ Jalan Ciledug Raya, Petukangan Utara, Jakarta Selatan, 12260
}

Submitted: 12 December 2020 Revised: 12 December 2020 Accepted : 13 December 2020

\begin{abstract}
Abstrak
Penelitian ini bertujuan untuk mengetahui representasi patriotisme dalam Film Soegija. Pertanyaan penelitian yang diajukan adalah bagaimana representasi patrotisme dalam Film Soegija. Metode penelitian ini adalah kualitatif dengan analisis Semiotika John Fiske. Objek penelitiannya adalah Film Soegija. Pengumpulan data diperoleh melalui observasi, dengan menggunakan teknik pengumpulan data primer dan sekunder. Data yang diperoleh langsung dari objek penelitian adalah Film Soegija. Hasil penelitian menunjukkan bahwa representasi patriotisme dari Film soegija dengan menggunakan kode realitas, representasi dan ideologi, melalui adegan percakapan, gambar teknik dan lokasi pengajuan. Film tersebut mengungkapkan bahwa karakter patriotisme menempatkan persatuan bangsa dan negara di atas kepentingan pribadi dan golongan, yaitu Soegija yang mencari cara untuk memulihkan keadaan menjadi baik, dengan melaksanakan perintah kepada setiap daerah untuk membentuk pemimpin daerah untuk mengatasi kekacauan. yang terjadi. Soegija memang memiliki kaidah agama sebagai pemimpin umat Katolik, kuat dalam membela gereja yang disucikan oleh umat Katolik. Soegija menganggap rakyat yang lebih menderita dan lebih membutuhkan makanan daripada pemimpin. Jika orang-orangnya penuh biarkan para pemimpin terakhir merasa kenyang. Dan biarlah jika rakyat lapar, pemimpin pertama merasa lapar. Soegija merasa sebagai seorang Katolik yang baik, juga harus menjadi seorang patriot yang baik dan saling mencintai. Soegija mementingkan kepentingan bersama, terutama kepentingan rakyat, agar bisa hidup lebih baik. Kesimpulan dari penelitian ini adalah Film Soegija berisi tentang Soegija yang memperjuangkan kemerdekaan Indonesia dengan mengedepankan kepentingan mayoritas, mengenang bahwa ia adalah seorang pemuka agama Katolik yang merupakan minoritas di Indonesia. Soegija menunjukkan dirinya sebagai pemimpin bangsa, bukan sebagai pemimpin Katolik.
\end{abstract}

Kata Kunci: film, patriotisme, representasi, semiotika John Fiske,

\section{Representation Of Patriotism In Soegija Film (John Fiske Semiotics Study)}

\begin{abstract}
This study aims to determine the representation of patriotism in the Soegija Film. The research question posed is how the representation of patrotism in the Soegija Film. The method of this research is qualitative with John Fiske semiotics analysis. His research object is Soegija Film. Data collection was obtained through observation, using primary and secondary data collection techniques. The data obtained directly from the research object is the Soegija Film. The results showed that the representation of Patriotism from the Soegija Film by using the code reality, representation and ideology, through the scene of conversation, technical drawing and location of the filing. The film reveals that the characteristic of patriotism places the unity of the nation and the state above personal and group interests, namely Soegija who seeks ways to restore conditions to good condition, by carrying out orders to each region to form regional leaders to overcome the chaos that occurs. Soegija really has a religious code as the leader of the Catholic community, strong in defending the church where sanctified by the Catholic community. Soegija considers the people who suffer more and need food more than the leader. If the people are full let the last leaders feel full. And let it be if the people are hungry, the first leader feels hungry. Soegija felt as a good Catholic, should also be a good patriot and love each other. Soegija attaches importance to the common interests, especially the interests of the people, so that they can live better. The conclusion of the research is The Soegija Film contains Soegija, who fought for
\end{abstract}


Indonesia's independence by prioritizing the interests of the majority, recalled that he was a Catholic religious leader who was a minority in Indonesia. Soegija showed himself as the leader of the nation, not the leader of Catholicism.

Keywords: Film, Patriotism, Representation, Semiotics John Fiske

\section{PENDAHUALUAN}

Film adalah sebuah sarana media komunikasi massa. Sebuah film dapat menyampaikan sebuah pesan komunikasi secara efektif serta lebih mudah dipahami, di ingat dan dimaknai oleh berbagai macam kalangan masyarakat. Sebuah film dapat berpengaruh terhadap perilaku sosial dalam masyarakat dari para penikmatnya sesuai dengan pesan apa yang di dapat dari sebuah film yang mereka nikmati. Film sebagai media komunikasi massa memiliki peran yang cukup penting yaitu sebagai alat untuk menyalurkan pesan-pesan kepada penontonnya (prasista. 2008), dengan pesan atau informasi yang dikemasi melalui rangkaian gambar atas dasar skenario bentuk cerita dan memiliki kebebasan dalam menyampaikannya kepada penontonya. Film sebagai salah satu komunikasi massa, film dapat dengan mudah mempengaruhi pemikiran pada suatu opini publik. Pesan komunikasi dalam film terwujud pada sebuah alur cerita yang dibawa film tersebut kemudian dirangkum dalam bentuk drama, action, komedi, horror. Cerita film berdasarkan riwayat hidup, kisah nyata, atau hanya sebuah rekaan (fiktif).

Tidak hanya film dengan pesan moral saja yang bisa dianalisis, tetapi juga film dengan makna yang tersirat serta simbol-simbol, dapat kita ketahui dengan menggunakan analisis semiotika yang merupakan salah satu ilmu dalam komunikasi. Semiotika adalah ilmu tentang tanda-tanda. Studi tentang tanda dan segala yang berhubungan dengannya, cara berfungsinya, hubungannya dengan tanda-tanda lain, pengirimannya dan penerimaannya oleh mereka yang menggunakannya. Semiotik mempelajari sistem-sistem, aturan-aturan, konvensi-konvensi yang memungkinkan tanda-tanda tersebut mempunyai arti (Kriyantono. 2006), film bertemakan perjuangan nasional pun tidak mau kalah dalam meramaikan perfilman Indonesia, Hingga kini film bertema perjuangan nasional seperti ikut bangkit. Film bertema perjuangan mulai mengisi layar bioskop. Film Indonesia yang bersifat patriot tersebut seolah ingin menyadarkan kita, betapa susahnya perjuangan para pahlawan kita dimasa itu sehingga sebagai generasi penerus, kita diimbau untuk memiliki ketangguhan seperti pahlawan saat itu. Sebagian besar dari kita mungkin akan langsung mengkaitkan satu tema ini dengan kerelaan seseorang untuk berkorban di medan perang demi Negara tercinta. Banyak hal-hal yang harus dijunjung oleh seoseorang untuk bisa disebut sebagai seorang patriot sejati. Patriotisme berbicara akan cinta dan loyalitas.

Secara awam patriotisme berasal dari kata "patriot" dan "isme" yang berarti sifat kepahlawanan atau jiwa pahlawan (Indonesia) atau heroism dan patriotism (Inggris). Patriotisme adalah suatu sikap yang berani, pantang menyerah dan rela berkorban demi bangsa dan negara. Pengorbanan tersebut dapat berupa pengorbanan harta benda maupun jiwa raga. Ervin Staub (1997) menyatakan patriotisme sebagai sebuah keterikatan (attachment) seseorang pada kelompoknya (suku, bangsa, partai politik, dan sebagainya). Keterikatan ini meliputi kerelaan sesorang dalam mengidentifikasikan dirinya pada suatu kelompok sosial (attachment) untuk selanjunya menjadi loyal. Staub juga membagi 
Patriotisme dalam dua bagian, yaitu blind patriotsm (patriotisme buta) dan constructive patriotism (patriotisme konstruktif). "Blind patriotism is defined as an attachment to country characterized by unquestioning positif evaluation, staunch allegiance, and intolerance of critism". Melihat definisi tersebut, dimana patriotisme buta dengan ciri khas menuntut tidak adanya evaluasi positif dan tidak toleran terhadap kritik. Staub juga mengatakan bahwa blind patriotism tidak saja berakbat buruk bagi kelompok luar (outgroup), namun juga membahayakan kelompoknya sendiri (ingroup). Tidak adanya kritik maupun evaluasi sama saja dengan membiarkan kelompok berjalan tanpa peta, hingga bisa terpeleset dan masuk jurang.

Film merupakan bidang kajian yang sangat relevan bagi analisis struktural semiotika. Menurut Van Zoest, film dibangun dengan tanda- tanda semata, tanda-tanda itu termasuk berbagai sistem tanda yang bekerja sama dengan baik untuk mencapai efek yang diharapakan, rangkaian gambar dalam film menciptakan imaji dan sistem penandaan (Sobur, 2004 : 128). Tokoh cerita adalah indvidu rekaan yang mengalami peristiwa atau perlakuan didalam berbagai peristiwa cerita. Jadi tokoh adalah subjek yang menggerakkan peristiwaperistiwa cerita, tema serta dialog. Tokoh dilengkapi dengan watak atau karakteristik tertentu. Watak atau karakter adalah yang menggerakan tokoh untuk melakukan perbuatan tertentu sehingga cerita menjadi hidup (Suharto.2002:45). Istilah tokoh menunjuk pada pelaku cerita, sedangkan istilah penokohan merupakan cara pengarang menggambarkan dan mengembangkan karakter tokoh - tokoh dalam cerita (Hidayati.2006:17).

Selain hal diatas, patriotisme konstruktif terdapat 2 (dua) faktor penting yaitu mencintai dan menjunjung tinggi nilai-nilai kemanusiaan. Disinilah diperlukan sikap peduli yang muncul dalam kritik dan evaluasi. Film "Soegija" adalah salah satu film yang bertemakan perjuangan nasional. Karena pada film ini diambil berdasarkan sejarah perjuangan kemerdekaan Indonesia pada tahun 1940-1949 saat terjadinya peristiwa Agresi Militer Belanda I ke jantung pemerintahan Republik Indonesia di Jawa Tengah. Bagaimana adegan-adegan dalam film menggambarkan perjuangan para pahlawan dimasa peperangan itu. Soegija adalah film yang ingin melukiskan kisah-kisah kemanusiaan di masa perang kemerdekaaan bangsa Indonesia pada tahun 1940-1949. Adalah Soegija (diperankan Nirwan Dewanto) yang diangkat menjadi uskup pribumi dalam Gereja Katolik Indonesia. Baginya kemanusiaan itu satu, kendati berbeda bangsa, asal-usul, dan ragamnya. media khususnya film sebagai sarana komunikasi media massa tidak dapat dikatakan netral. Karena melihat sajian film Seogija yang diambil dari catatan harian Mgr. Albertus Seogijapranata, S.J memiliki sedikit banyak perbedaan antara data sejarah dan fakta yang ditampilkan dalam film tersebut. Film ini mencoba mengkonstruksikan kembali sosok perjuangan Mgr. Albertus Soegijapranata, S.J melalui adegan- adegan tertentu yang sudah dikemas secara sederhana dan menarik.

Sebagai bahan referensi dalam melakukan penelitian mengenai representasi patriotisme dalam film "Soegija", penulis mengambil beberapa penelitian terlebih dahulu yang membahas mengenai obyek atau penelitian yang sejenis. Beberapa penelitian terdahulu tersebut, antara lain dilakukan oleh Fransiskus Xaverius Diaz tahun 2017 berjudul Pengadeganan Tokoh Soegija Dalam Film Soegija Karya Garin Nugroho (Studi Analisis Semiotika Charles Sanders Peirce). Pengadeganan Soegija dapat dianalisis dengan 
menggunakan semiotika Peirce yang dimunculkan melalui tanda-tanda, seperti pada adegan pertama yang menunjukan sikap Soegija mengunjungi umatnya untuk memberikan dukungan moral kepada umatnya. Adegan kedua menunjukan sifat pemberani dari Soegija yang melindungi gereja dari tentara Jepang, walaupun nyawanya menjadi taruhan. Adegan ketiga menunjukan Soegija yang mendahulukan kepentingan rakyat daripada kepentingannya sendiri. Adegan keempat menunjukan Soegija yang berjuang dengan cara perundingan/ diplomasi untuk menghentikan peperangan. Adegan kelima menunjukan solidaritas Soegija yang membuka gereja untuk para pengungsi. Adegan keenam menunjukan semangat kebersamaan antara Soegija dan masyarakat untuk mendukung perjuangan.

Penelitian Maria Desi Kritianingrum tahun 2013 berjudul Konstruksi Sosok Perjuangan Mgr. Albertus Soegijapranata, S.J dalam Film Soegija. media khususnya film sebagai sarana komunikasi media massa tidak dapat dikatakan netral. Karena melihat sajian film Seogija yang diambil dari catatan harian Mgr. Albertus Seogijapranata, S.J memiliki sedikit banyak perbedaan antara data sejarah dan fakta yang ditampilkan dalam film tersebut. Film ini mencoba mengkonstruksikan kembali sosok perjuangan Mgr. Albertus Soegijapranata, S.J melalui adegan- adegan tertentu yang sudah dikemas secara sederhana dan menarik.

Penelitian karya Fitriana Handayani tahun 2010 berjudul Representasi Pluralisme Agama dalam Majalah Madina (Analisis Semiotika Charles Saunders Peirce). Pada level teks wacana pluralisme agama direpresentasikan melalui pemilihan kata, tata bahasa dan analisis hubungan serta identitas yang menyusun tulisan tersebut. Analisis dipresentasikan melalui pilihan kata, tata bahasa dan analisis hubungan serta identitas yang menyusun tulisan tersebut. Analisis level praktik wacana menunjukan bahwa staf redaksi memaknai pluralisme agama sebagai paham yang menjunjung tinggi toleransi beragama. Sedangkan pada level sosiokultural menunjukan bahwa pluralisme agama tumbuh akibat transisi sosial yang berlangsung di masyarakat. Proses transisi tersebut berimplikasi pada kerapnya konflik agama, kekerasan atas nama agama kemunculan agama baru dan kantong-kantong pemikiran baru islam terjadi di Indonesia.

Penelitian karya Devi Novitasari (2014) dalam jurnalnya yang berjudul Penokohan Tionghoa Peranakan Jawa Dalam Film Indonesia Berjudul "Soegija”, Jurusan Seni Media Rekam, Fakultas Seni Rupa dan Desain, Institut Seni Indonesia Surakarta, memiliki pesamaan dalam penelitian yaitu film Soegija. Perbedaannya, jurnal ini mengemukakan bagaimana penokohan tiga dimensi karakter yaitu fisiologis, psikologis dan sosiologis pada film Soegija, sedangkan penelitian ini mengemukakan pengadeganan Soegija dalam film Soegija. Peneliti mengangkat film "Soegija" sebagai studi kasus untuk penelitian ini, karena peneliti melihat banyak adegan-adegan di film ini yang peneliti pandang menampilkan nilainilai patriotisme. Dalam film ini banyak menampilkan adegan-adegan sebuah perjuangan dalam membela bangsa yang menjunjung tinggi nilai-nilai kemanusiaan. Pada penelitian ini peneliti menggunakan studi semiotika John Fiske untuk melihat bagaimana representasi patriotisme ditampilkan pada film "Soegija". 


\section{METODE PENELITIAN}

Penelitian ini menggunakan paradigma kritis. Alasan peneliti menggunakan paradigma kritis dalam penelitian ini dikarenakan peneliti akan mengungkap dan membongkar hal yang mendalam mengenai suatu dominasi dan ideologi yang hendak ditanamkan dalam film Soegija. Peneliti menduga terdapat adanya dominasi ideologi Patriotisme yang terdapat pada film Soegija. Paradigma kritis akan membantu peneliti untuk melihat dan kemudian menguak makna yang tersembunyi dari film Soegija dari tanda-tanda yang dimunculkan pada film ini.

Mengacu pada pokok permasalahan yang ada, penelitian ini menggunakan pendekatan kualitatif. Pengertian pendekatan kualitatif menurut Bogdan dan Tayler yang dikutip oleh Bagong Suyanto dan Sutinah, yaitu sebagai "prosedur penelitian yang menghasilkan data deskriptif berupa kata-kata tertulis atau lisan dari orang-orang dan perilaku yang dapat diamati" (Suyanto, Sutinah, 2005:166).

Untuk mengetahui representasi Patriotisme dalam film Soegija, peneliti menggunakan metode dengan analisis semiotika John Fiske. semiotika adalah ilmu yang mengkaji tanda dalam kehidupan manusia. Semua tanda yang ada di kehidupan manusia memiliki makna atau arti, dengan kata lain ilmu semiotika adalah ilmu yang mempelajari tentang makna yang ada dalam sebuah tanda (Hoed, 2014:15). Analisis ini terdiri dari tiga tahap pengkodean yaitu, realitas, representasi dan ideologi.

- Level Realitas

Peristiwa yang di tandakan (encode) sebagai realitas, bagaimana peristiwa itu dikonstruksi sebagai realitas oleh wartawan atau media. Dalam bahasa gambar (terutama televisi) ini umumnya berhubungan dengan aspek seperti Penampilan, kostum, rias, lingkungan tingkah laku, cara bicara, gerak tubuh, ekspresi, suara. Di sini, realitas selalu di tandakan, ketika kita menganggap dan menkonstruksi peristiwa tersebut sebagai sebuah realitas.

- Level Representasi

Ketika kita memandang sesuatu sebagai realitas, pertanyaan berikutnya adalah bagaimana realitas itu di gambarkan. Di sini kita menggunakan perangkat teknis, dalam bahasa tulis, alat-alat itu adalah kata, kalimat atau proporsi, grafik dan sebagainya. Dalam bahasa atau gambar di televisi, alat itu berupa Kamera, cahaya, editing, musik, suara yang mentransmisikan kode-kode representasi dari, contohnya: Naratif, konflik, karakter, aksi, dialog, setting, casting. Pemakaian dengan kata-kata, kalimat, atau proporsi tertentu ketika di terima oleh masyarakat.

- Level Ideologi

Bagaimana peristiwa tersebut terorganisirkan ke dalam konvensi-konvensi yang diterima secara ideologis. Bagaimana kode-kode representasi di hubungkan dan di organisasikan ke dalam koheransi sosial seperti kelas sosial, atau kepercayaan dominan, yang ada dalam masyarakat (patriaki, materialisme, kapitalisme, dan sebagainya. 


\section{HASIL DAN PEMBAHASAN}

Peneliti menemukan beberapa scene dalam film Soegija ini terdapat representasi dari Patriotisme. Film selalu mempengaruhi dan membentuk masyarakat berdasarkan muatan pesan di baliknya, tanpa pernah berlaku sebaliknya. Kritik yang muncul terhadap perspektif ini didasarkan atas Argumen bahwa film adalah potret dari masyarakat di mana film itu dibuat (sobur. 2016:127). Pada unsur "mempengaruhi dan membentuk masyarakat" merupakan hal yang dapat bersifat positif maupun negatif. Soegija adalah film drama epik sejarah dari Indonesia yang diproduksi Puskat Pictures hasil besutan sutradara senior Indonesia Garin Nugroho, di produseri oleh Dajduk Ferianto, Murti Hadi Wijayanto SJ, Tri Giovanni dan dibintangi oleh budayawan Nirwan Dewanto yang memerankan tokoh pahlawan nasional Albertus Soegijapranata. Film yang dibintangi aktor-aktor dari beragam latar belakang budaya ini diluncurkan di Indonesia pada tanggal 7 Juni 2012. Dengan anggaran sekitar Rp 12 Miliar, film ini menjadi film termahal yang disutradarai Garin Nugroho.

Film yang pengambilan gambarnya di Gereja Gedangan Semarang, pada 7 November 2011. Selain Semarang, dilanjutkan pengambilan gambar di Yogyakarta, Pabrik Gula Gondang Klaten, serta kawasan Ambarawa. Film ini juga berhasil menyabet dua penghargaan untuk kategori Sutradara Terbaik dan Film Terbaik dalam Festival Film Kine Klub 2012. Film ini juga menampilkan tokoh-tokoh nasional Indonesia lain, seperti Soekarno, Fatmawati, Mohammad Hatta, Sutan Sjahrir, Sri Sultan Hamengkubuwana IX, Sri Paku Alam VIII, Jenderal Soedirman, Soeharto, dll.

Untuk bisa menggambarkan pengalaman Soegija, film ini banyak menampilkan tokoh-tokoh nyata tapi difiksikan baik dari Indonesia, Jepang, Belanda, sipil maupun militer dalam peristiwa-peristiwa keseharian yang direkonstruksi dengan cukup detil. Film "Soegija" bukanlah film biografi tentang sosok Uskup Indonesia pribumi pertama yang memangku tugas dan jabatan sebagai Uskup Vikariat Semarang, melainkan lebih merupakan paparan visual melalui media film tentang sikap Gereja Indonesia dalam menyikapi persoalan kemanusiaan dan tantangan serius negara Indonesia dalam upaya mempertahankan kemerdekaannya.

Film Soegija menampilkan sosok seorang patriot. Seorang patriot yang berasal dari kalangan minoritas karena dia seorang uskup atau pemimpin umat Katolik. Film merupakan salah satu media massa yang mempunyai pengaruh cukup besar dalam bentuk persepsi masyarakat. Menggambarkan sebuah karakter bisa dengan menggunakan representasi, karena representasi akan menggambarkan sebuah karakter yang cukup jelas. Setelah melakukan analisis semiotika John Fiske melalui kode-kode televisi level ralitas, level representasi sehingga membentuk sebuah ideologi, maka peneliti dapat menjawab pertanyaan masalah dari penelitian ini yang dicantumkan pada bab 1, yaitu bagaimanakah representasi patriotisme dalam Film "Soegija". Berikut hasil analisis: 


\section{a. Sikap Patriotisme Kemanusiaan}

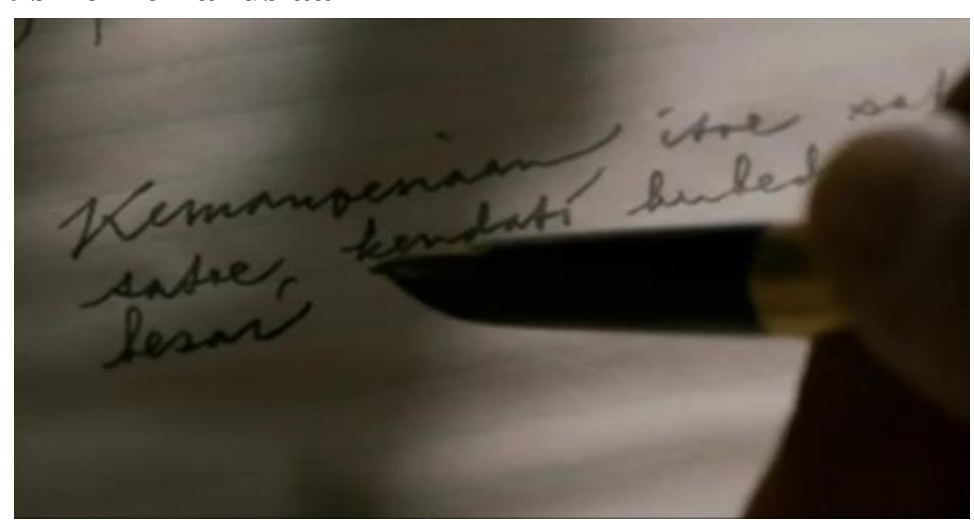

Sumber: objek penelitian, 2020

Gambar 1 : Representasi Patriotisme Kemanusiaan

Pada gambar ini menceritakan pada tahun 1940 Soegija sedang menulis di atas kertas tentang ungkapan hatinya mengenai kemanusiaan. Pada scene ini menunjukan sikap patriotisme nilai kemanusiaan. Soegija yang menjunjung tinggi nilai-nilai kenausiaan. Bagi Soegija, walaupun manusia di bumi berasal dara bangsa, suku dan agama yang berbeda. Namun baginya kemanusiaan itu satu. Dilihat makna patriotisme dari level representasi, yaitu kode dialog. Soegija mengatakan "1940. Kemanusiaan itu satu. Bangsa manusia itu satu. Kendati berbeda merupakan satu keluarga besar." Dari tanda yang terdengar dalam kode dialog tersebut, Terlihat bagaimana Soegija mempunyai nilai kemanusiaan yang tinggi. Bagi Soegija, walaupun manusia di bumi ini berasal dari berbagai suku bangsa, berbeda agama tetap semuanya satu keluarga besar. Kode ideologi yang terdapat pada scene ini, yaitu Ideologi pariotisme dengan nilai kemanusiaan. Bagi Soegija kemanusiaan itu satu. Kemanusiaan tidak berkotakkan oleh perbedaan agama, suku, bangsa, bahasa, maupun golangan. Kemanusiaan itu cultural, yang mempunyai hak yang sama.

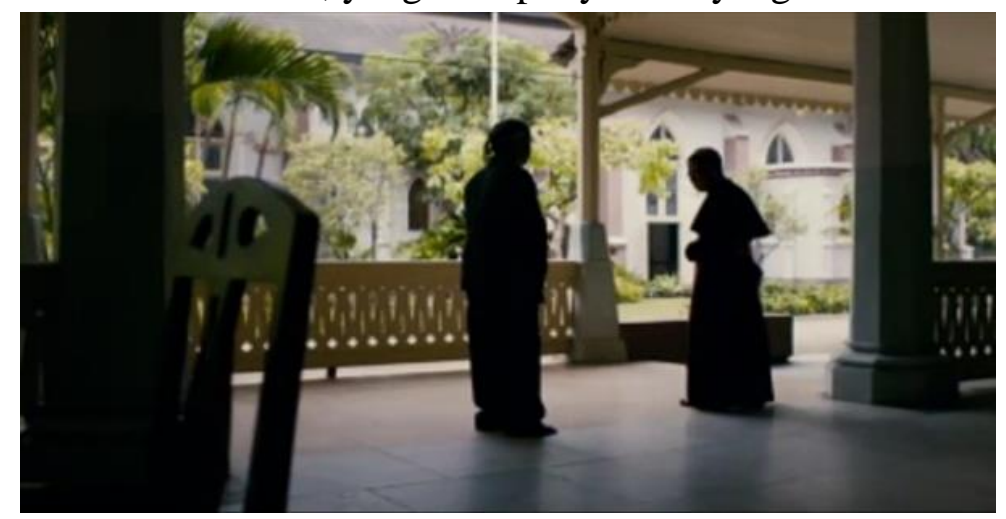

Sumber: objek penelitian, 2020

Gambar 2 : Representasi Patriotisme Kemanusiaan

Pada gambar ini Toegimin bertanya kepada Soegija apa yang harus dilakukan ketika Jepang datang sebagai kekuatan baru di Indonesia. Pada scane ini menunjukan sikap 
patrioisme nilai kemanusiaan. Karena Soegija sedih menahan tangis atas apa yang dialami oleh Indonesia pada saat itu.

Pada level realitas yang terdapat pada kode ekspresi, Soegija yang menangis dan terlihat begitu sedih ketika gereja akan disita untuk dijadikan markas Jepang. Menunjukan patriotisme dengan nilai kemanusiaan, karena begitu sedih ketika melihat apa yang dialami Indonesia pada saat itu pastor-pastor dan suster-suster Belanda di sandera Jepang. Kejadian itu membuat Soegija harus berjuang meghadapi Jepang untuk menyelematkan Indoensia.

Kode ideologi dari yang terdapat pada adegan ini, yaitu Ideologi patriotisme kemanusiaan dan pluralisme. Karena pada adegan ini, Soegija sangat sedih hingga menangis karena Indonesia saat Jepang menyandera pastor dan suster Belanda dan warga sipil di sandera oleh tentara Jepang dan sedih karena Soegija tak bisa berbuat apa-apa. Kode ini menunjukan tanda walaupun berbeda Negara, namun bagi Soegija Belanda sudah menjadi bagian dari Indonesia dengan tetap hidup rukun, saling menghormati dan tolong-menolong .

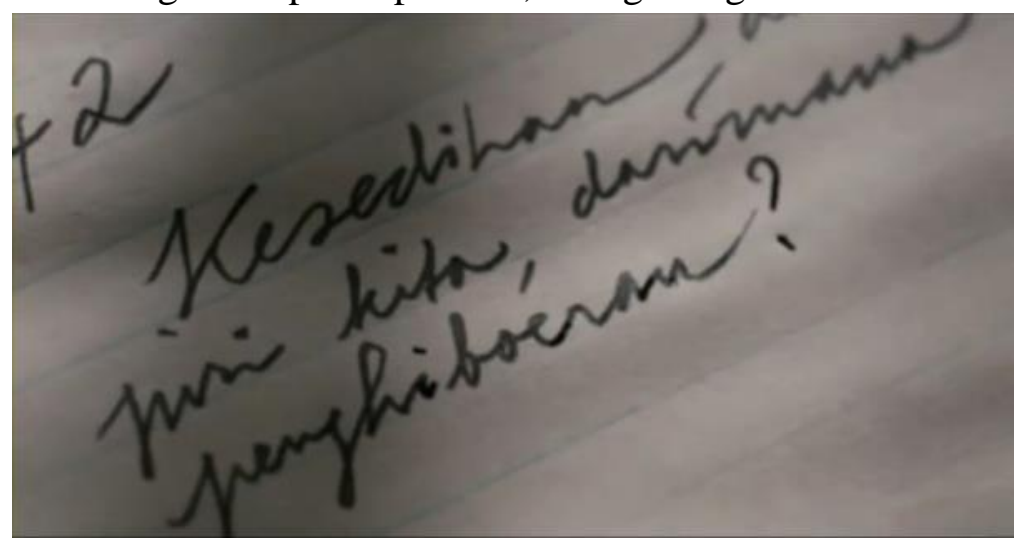

Sumber: objek penelitian, 2020

Gambar 3 : Representasi Patriotisme Kemanusiaan

Pada gambar ini Soegija yang menuliskan catatan hariannya pada tahun 1942 yang berisi kesedihan dan penderitaan yang sedang menghampiri Indonesia. Pada scene ini menunjukan sikap patriotisme nilai kemanusiaan. Soegija yang menuangkan ungkapan hatinya ke catatan hariannya tentang kesedihan dan penderitaan yang sedang menghampiri Indonesia, dan bertanya dimana Indonesia mendapatkan kekuatan dan penghiburan?

Pada level realiatas berdasarkan cara berbicara yaitu cara berbicara Soegija tenang dengan penuh harapan tentang apa yang dialami Indoensia pada tahun 1942. Rasa kemanusiaan Soegija itulah yang menbuat dirinya harus berjuangan. Dari keheningan batinnya itulah ia dapatkan keberanian untuk menghadapi siapa saja yang akan merampas negerinya. Kode cahaya yang kurang pencahayaan seperti didalam ruangan untuk menunjukan keheningan dan kesendirian hati.

Level ideologi patriotisme kemanusiaan, yaitu Soegija mempunya rasa kepedulian atas apa yang sedang dialami negaranya dan sedang merenungkan apa yang harus dilakukannya agar kesedihan dan penderitaan berakhir menghampiri rakyat. Sifat kepedulian Soegija sangatlah kuat, agar masyarakat tak lagi merasakan penderitaan terlalu lama. 


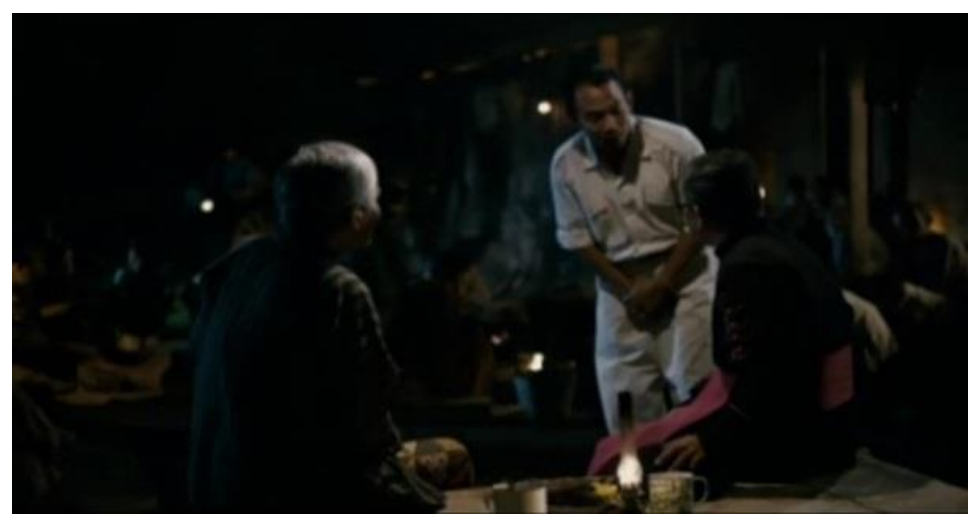

Sumber: objek penelitian, 2020

Gambar 4 : Representasi Patriotisme Kemanusiaan

Pada gambar ini Soegija yang sedang berbincang-bincang dengan bapak lurah di pengungsian penduduk. Pada scene ini terlihat sikap patriotisme kemanusiaan, Soegija menganggap bahwa jika rakyat lapar, biar para imam yang pertama merasa lapar. Karena sebagai seorang khatolik yang baik dan sebagai patriot baik pula, kita harus mengasihi sesama.

Dilihat dari level representasi kode dialog ketika Soegija berkata "Bapak Lurah, rakyat sedang sangat menderita dimana-mana. Mereka sangat kelaparan, bagikan makanan itu lebih dulu kependuduk. Jika rakyat kenyang, biar para imam yang terakhir merasa kenyang. jika rakyat lapar, biar para imam yang pertama merasa lapar." Bagi Soegija rakyatlah yang terpenting, karna rakyat yang lebih menderita dibandingkan para pastor. Dan Soegija juga mengatakan "Ini saatnya kita terpanggil mempertahankan hak Allah, hak agama, dan hak bangsa kita. Kita harus mengasihi gereja, dan dengan begitu kita juga mengasihi Negara. Sebagai orang Katolik yang baik. Mestinya kita juga patriot yang baik. Seratus persen republik. Sebab kita merasa Seratus persen Katolik.” bagi Soegija menjadi orang Katolik yang baik, kita juga harus menjadi patriot yang baik. Karena sebagai umat Katolik kita harus saling mengasihi sesama.

Pada level ideologi terdapat ideologi patriotisme nilai kemanusiaan karena Soegija menganggap rakyatlah yang lebih menderita dan lebih membutuhkan makanan dibanding pemimpin. Jika rakyat kenyang biar para pemipin yang terakhir merasa kenyang. Dan biarlah jika rakyat lapar, pemimpin yang pertama merasa lapar. Soegija merasa sebagai seorang Katolik yang baik, mestinya juga menjadi patriot yang baik dan saling mengasihi.

\section{b. Sikap Patriotisme (ciri Rela Berkorban)}




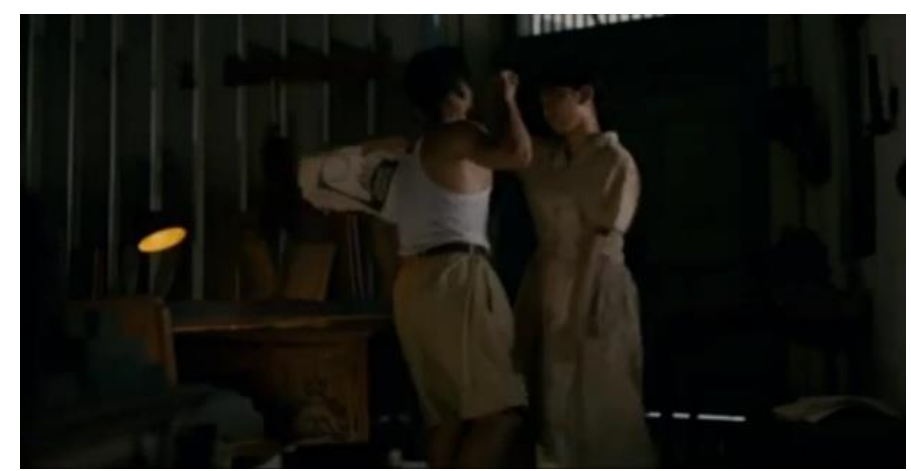

Sumber: objek penelitian, 2020

Gambar 5 : Representasi Patriotisme (Rela Berkorban)

Pada gambar ini Maryono memberitahukan Maryem tentang kepergiannya karena tugas yang diberikan Presiden Soekarno kepadanya. Pada scane ini menunjukan sikap patriotisme dengan ciri rela berkorban. Ketika Maryono harus pergi meninggalkan adiknya Maryem demi tugas untuk menyelamatkan Indoensia dikal itu.

Dilihat makna patriotisme dari level Realitas terdapat tanda yang berdasarkan kode kostum pakaian. Maryono yang menggunakan kaos dalam putih dimasukan ke dalam celana pendek berwarna coklat dan bersabuk. Celana pendek coklat yang digunakan Maryono menandakan bahwa dia adalah seorang pejuang pada tahun 1940an, pejuang identik berpakaian kemeja berwarna coklat dan celana pendek berwarna coklat pula. Pada tahap realitas ini juga terdapat tanda berdasarkan kode ekspresi, kode ekspresi yang terlihat pada gambar 1 ketika Maryono sedang berbicara kepada Maryem, ia terlihat serius dan sibuk mengumpulkan dokumen-dokumen penting. Ini menunjukan Meryono yang sangat bersemangat dan serius tentang keinginnannya untuk pergi bertugas karena itu salah satu jalan untuk mempertahankan kemerdekaan Indonesia.

Pada tahap level representasi ditemukan tanda yang berdasarkan kode-kode teknis yaitu kerja kamera, pengambilan gambar semuanya secara medium long shot dengan pengambilan sudut kamera normal angel untuk menunjukan keseluruhan ruangan dan posisi Maryono dan Maryem dalam berbincang-bincang. Pada gambar 3 terlihat Maryem berdiri untuk menghalangi Maryono pergi, pada gambar 4 terlihat Maryono mendorong Maryem hingga terjatuh sambil memegang lengan Maryem. Menunjukan Maryono yang mempunyai keinginan kuat untuk mengemban tugas demi menyelamatkan Indonesia, walaupun harus meninggalkan keluarga satu-satunya yaitu adiknya Maryem.

Sedangkan pada kode dialog yaitu perkataan Maryono kepada Maryem "Simpan ini dek, sembunyikan baik-baik. Soekarno bilang cepat selesaikan belanda. Mereka minta aku mencetak poster propaganda. Aku harus pergi dek." dari perkataan Maryono tersebut terlihat sikap patriotisme rela berkorban walaupun harus meninggalkan keluarga, Maryono rela meninggalkan adiknya demi tugas yang diembankan kepadanya.

Kode Ideologi yang terdapat pada adegan ini, yaitu ideologi patriotisme rela berkorban, dimana seseorang rela meninggalkan sanak saudara demi bangsa dan negaranya. Ideologi tersebut terlihat pada adegan Maryono pergi meninggalkan adiknya Maryem, keluarga satu-satunya yang dipunya Maryono. Tugas yang diberikan Soekarno Presiden 
Indonesia pada tahun 1940an itu menuntutnya untuk pergi meninggalkan keluarga demi menyelamatkan dan memperjuangkan kemerdekaan Indonesia, yang pada saat itu muncul Jepang sebagai kekuatan baru di Indonesia dan kedudukan Belanda di Indonesia yang melemah.

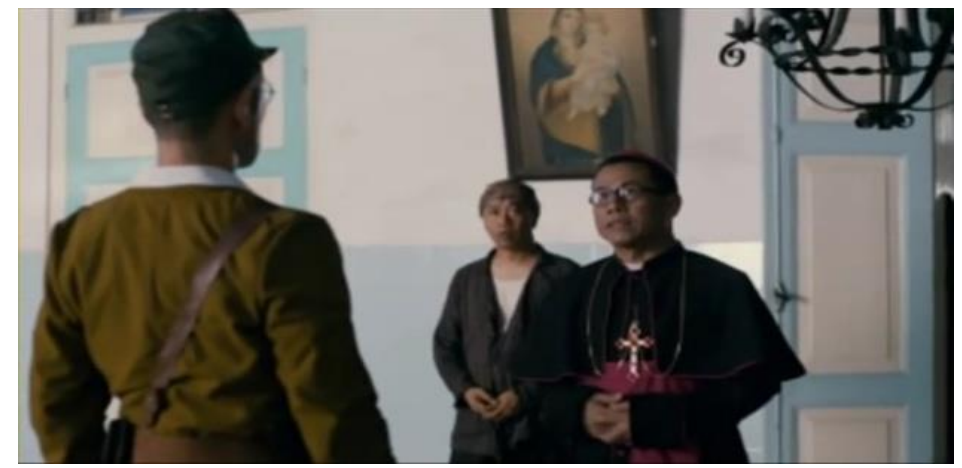

Sumber: objek penelitian, 2020

Gambar 6 : Representasi Patriotisme (Rela Berkorban)

Pada gambar ini Nobuzuki (pimpinan tentara Jepang) menemui Soegija untuk meminta alih fungsi gereja menjadi markas Jepang. Pada scene ini menunjukan sikap patriotisme dengan ciri rela berkorban, ketika Nobuzuki (pimpinan tentara Jepang) menemui Soegija untuk meminta alih fungsi gereja menjadi markas Jepang namun Soegija menentang keras hingga ia meminta Nobozuki untuk memenggal kepalanya terlebih dahulu baru Jepang boleh memakai gereja menjadi markas.

Dilihat dari level realitas berdaraskan kode kostum Nobuzuki dan Soegija. Pada Nobuzuki yang terlihat ialah mengenakan pakaian seragam militer jas rapi dengan penutup kepala realiatas dari perwira Jepang, menunjukan bahwa ia seorang dari kelas yang mempunyai pekerjaan sebagai tertinggi di tentara yang berpakaian jas rapi. Soegija menggunakan busana liturgy (busana yang dikenakan seorang uskup ketika dalam kegiatan keagamaan) dan menggunakan kalung berliontinkan salip yang merealitaskan seorang uskup atau pemimpin umat Katolik.

Sedangkan makna patriotisme dari dialog terlihat perkataan Soegija "Itu tempat yang disucikan! Penggal dulu kepala saya, baru Tuan boleh memakainya." Hal ini memperjelas bahwa Soegija yaitu seorang patriotisme yang rela berkorban karena rela jika kepalanya dipenggal untuk mempertahankan gereja, Soegija juga menunjukan bahwa dia sebagai pemimpin umat Katolik yang taat dan mempunyai rasa kemanusian yang tinggi demi menyelamatkan masyarakat. Pada level ideologi terdapat patriotisme kemanusiaan dan rela berkorban. Dimana Soegija rela dipenggal kepalanya apabila gereja dijadikan untuk markas Jepang, dan Soegija benar-benar mempunyai kode agama sebagai pemimpin umat Katolik, bersikuat untuk mempertahankan gereja tempat yang disucikan oleh umat Katolik.

\section{c. Sikap Patriotisme (ciri Cinta Tanah Air)}




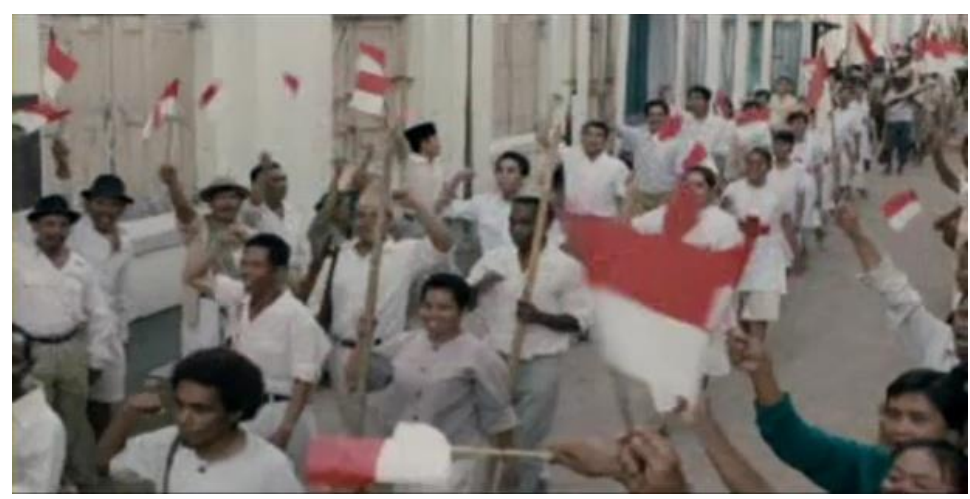

Sumber: objek penelitian, 2020

Gambar 7 : Representasi Patriotisme (Cinta Tanah Air)

Pada gambar ini Lantip sedang berada dipinggir kota sambil menyerukan kemerdekaan Republik Indonesia. Pada scane ini terlihat sikap patriotisme ciri cinta tanah air, yaitu Lantip sedang berada dipinggir kota yang bersemangat menyerukan kemerdekaan Republik Indonesia. Karena pada tanggal 17 Agustus Bung Karno dan Bung Hatta telah mengumandangkan proklamasi kemerdekaan Indonesia.

Ditemukan tanda dalam level Realitas seperti kode gerakan Lantip dan masyarakat dengan mengangkat tinggi-tinggi dan mengenggam tangan kanannya menunjukan semangat kemerdekaan. Kode gerakan juga terdapat pada barisan masyarakat yang mengangkat tinggi bendera Indonesia, ini menggambarkan kemerdekaan Indonesia.

Sedangkan kode ekspresi, terlihat pada Lantip dengan suaranya yang keras hingga mulutnya terbuka lebar, hal itu menggambarkan kegembiraannya atas kemerdekaan Indonesia dan semangatnya yang berkobar-kobar untuk terus berjuang.

Sedangkan pada level representasi terdapat pada kode dialog yang terlihat pada Lantip mengatakan "tanggal 17 Agustus ini, Bung karno dan Bung Hatta telah mengumandangkan proklamasi kemerdekaan Indonesia. Kita sudah merdeka saudara-saudara! kita sudah punya Negara sendiri! Mereka! Merdeka! Merdeka! Ayo kita bergabung untuk merayakan kemerdekaan. Merdeka! semuanya merdeka! Merdeka!” Kode dialog yang terdapat pada scene ini menunjukan bahwa Lantip sangat bergembira dengan kemerdekaan Indoensia yang diproklamasikan oleh Presiden Soekarno pada tanggal 17 Agustus 1945. Dengan semangat yang mengebu-gebu, nada suara yang keras mengajak seluruh rakyat Indonesia untuk terus bangkit, karena Indonesia sudah menjadi Negara yang berdiri sendiri tanpa adanyanya pengaruh bangsa lain.

Pada tahap level ideologi pada scene ini yaitu ideologi nasionalisme, Lantip yang begitu bergembira dan bersemangat menyerukan kemerdekaan Republik Indonesia dengan berteriak keras sambil mengepalkan tangannya dan dinaikkan keatas, diiringi dengan masyarakat yang mengibarkan bendera merah putih yaitu bendera Indonesia, karena merasa bangga dan senang atas kemerdekaan Indonesia.

\section{d. Sikap Patriotisme (ciri Menempatkan Persatuan dan Kesatuan Bangsa dan Negara Diatas Kepentingan Pribadi dan Golongan)}




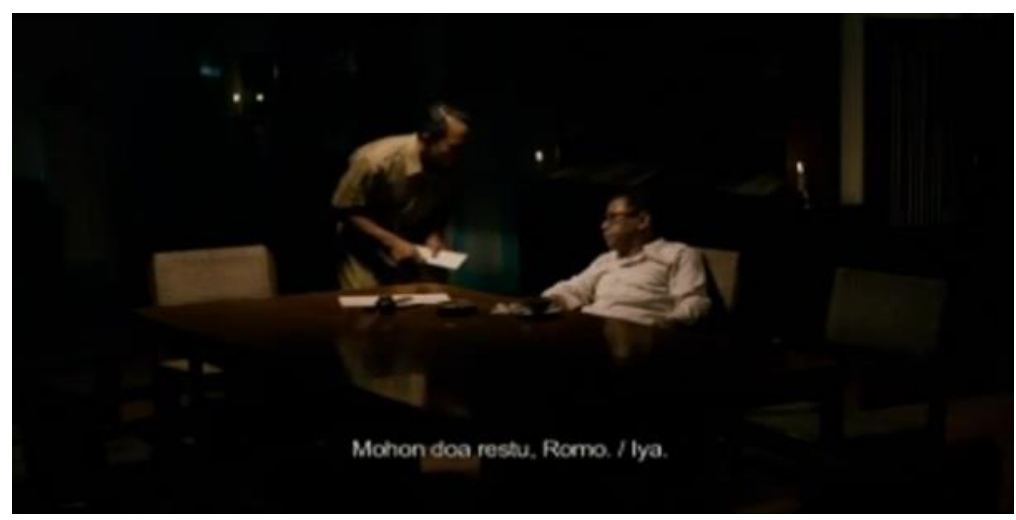

Sumber: objek penelitian, 2020

Gambar 8 : Representasi Patriotisme

Pada gambar ini Soegija yang sedang berbincang-bincang bersama Lantip, dan memperintahkan Lantip untuk menyerahkan surat kepada Perdana Mentri Syahril di Semarang agar segera dibentuk pemerintahan didaerah, untuk mengatasi bencana dan kekacauan yang menimpa penduduk. Pada scene yang terlihat patriotisme menempatkan persatuan dan kesatuan bangsa dan negara diatas kepentingan pribadi dan golongan ketika Soegija yang sedang berbincang-bincang bersama Lantip, dan memperintahkan Lantip untuk menyerahkan surat kepada Perdana Menteri Syahril di Semarang agar segera dibentuk pemerintahan didaerah, untuk mengatasi bencana dan kekacauan yang menimpa penduduk. Karena menurut Soegija keadaan tak bisa dibiarkan berlarut-larut dan Soegija akan mengupayakan gencatan senjata.

Patriotisme dari level representasi, terdapat pada kode dialog ketika Soegija mengatakan "Berikan kepada Perdana Menteri Syahril. Supaya di Semarang segera dibentuk, pemerintahan daerah. Untuk mengatasi bencana dan kekacauan yang menimpa penduduk. Keadaan tak bisa dibiarkan berlarut-larut. Aku akan mengupayakan gencatan senjata. Secepatnya!" Kode dialog tersebut menunjukan tanda bahwa Soegija tidak bisa membiarkan rakyat terus menerus menderita, dia harus melakukan upaya untuk mengakhiri sutuasi yang kacau.

Pada tahap level representasi terdapat tanda yang berdasarkan kode-kode teknis yaitu kerja kamera dan kode dialog. Pengambilan gambar secara over shoulder shot seukuran medium shot dalam sinematografi biasanya ini digunakan mengesankan objek yang diambil dari belakang punggung, dengan subyek utama berada dibalik punggung subyek lainnya, tetapi hal ini ditunjukan kepada penonton sebagai posisi Nobozuki yang sedang berinteraksi dengan Soegija dengan pengambilan sudut kamera secara normal angel yang sesuai dengan pandangan mata, dengan pencahayaan fill light yang terlihat natural, depp focus kode ini memperlihatkan semua ekspresi wajah Soegija juga Toegimin dan posisi berdiri Nobozuki yang tegap.

Pada level ini terdapat ideologi patriotisme ciri menempatkan persatuan kesatuan bangsa dan negara diatas kepentingan pribadi dan golongan, yaitu Soegija yang mencari cara agar dapat mengembalikan kondisi menjadi baik, dengan melakukan perintah ke setiap daerah agar dibentuk pimpinan daerah untuk mengatasi kekacauan yang terjadi. Soegija 
mementingkan kepentingan bersama, terlebih kepentingan rakyat, agar dapat hidup lebih baik.

\section{SIMPULAN}

Pembedahan unsur ideologi pada film ini menggunakan analisis semiotika John Fiske. Berdasarkan penelitian yang telah dilakukan oleh peneliti, maka penelitian dengan judul "Representasi Patriotisme Dalam Film Soegija" yang menggunakan metode analisis secara Interpretatif dengan menggunakan teori analisis semiotika kode-kode televisi John Fiske, maka tiap tanda dalam film "Soegija" yang dianalisis melalui level realitas, level representasi dan ideologi. Teori Semiotika John Fiske adalah tepat dalam menemukan unsur ideologi yang tertanam pada film Soegija.

Pada tahapan pertama yaitu level realitas, yang mendominasi dalam film "Soegija" ini adalah kategori kostum, riasan (makeup), penampilan, cara berbicara, gerak-gerik, suara, ekspresi seperti kode kostum pada Lantip yang memakai kemeja putih dan celana panjang cream bertopikan pejuang yang identik dengan pakaian berwarna cream ditambah dengan penutup kepala dimasa penjajahan tahun 1940an.. Sedangkan pada tahapan kedua yaitu Level Representasi, yang mendominasi adalah representasi kode kamera, pencahayaan, editing, musik, dan suara.

Film "Soegija" telah merepresentasikan patriotisme yang ditampilkan melalui adeganadegan sikap patriotisme dengan perilaku tokoh-tokoh yang digambarkan dalam film Soegija, yaitu Soegija yang rela dipenggal kepalanya ketika Nobozuki meminta gereja dijadikan markas untuk Jepang, karena menurut Soegija gereja adalah tempat yang disucikan. Soegija juga memerintahkan Bapak Lurah untuk terlebih dahulu memberikan makanan kepada penduduk baru kepada pemimpin, Soegija mengatakan kepada Bapak Lurah dan Lantip ketika merasa lapar pemimpinlah yang seharusnya merasa lapar terlebih dahulu dibandinggkan rakyat, karena bagi Soegija sebagai khatolik yang baik kita juga harus menjadi patriot yang baik, dan Soegija juga melakukan client diplomacy untuk mengupayakan gencatan senjata kepada pimpinan jepang dengan memanfaatkan hubungan diplomatik dengan Vatikan, dimana Soegija berupaya mempertahankan kemerdekaannya dalam perspektif nasionalisme yang mengedepankan kemanusiaan tanpa harus melihat golongan. Dimana setiap perjuangan tidak hanya dilakukan dengan berjibaku dengan senjata dan keberanian saja, tetapi bisa dengan suatu pola fikir yang diplomatis dan menjunjung tinggi nilai-nilai kemanusiaan.

Tahap terakhir atau tahap ke tiga yaitu level ideologi, yang mendominasi adalah patriotisme dan nasionalisme. Patriotisme yang ditampilkan dalam film "Soegija" salah satu bentuk realitas faktual. Film Soegija bukanlah film biografi tentang sosok Uskup Indonesia pribumi pertama yang memangku tugas dan jabatan sebagai Uskup Vikariat Semarang, melainkan lebih merupakan paparan visual melalui media film tentang sikap Gereja Indonesia dalam menyikapi persoalan kemanusiaan dan tantangan serius negara Indonesia dalam upaya mempertahankan kemerdekaannya. Soegija yang memperjuangkan kemerdekaan Indonesia dengan mementingkan kepentingan mayoritas, mengingat dia adalah 
seorang tokoh pemuka agama Katolik yang menjadi golongan minoritas di Indonesia. Soegija menunjukkan dirinya sebagai pemimpin bangsa, bukan pemimpin agama Katolik.

Setelah menemukan kesimpulan dari penelitian ini, maka peneliti ingin memberikan saran teoritis bagi peneliti komunikasi, yaitu teori semiotika John Fiske dapat digunakan untuk meneliti makna pesan dalam media massa elektronik yang audio-visual, seperti film, program acara televisi, program berita, drama atau opera, iklan televisi dan sebagainya. Terutama untuk mengungkapkan nilai-nilai ideologi dibalik pesan yang disampaikan dan terlihat adanya maksud tertentu dalam pemakaian tanda-tanda pada audio visual. peneliti juga memberikan saran praktis untuk insan perfilman Indoensia agar dalam membuat film yang bertujuan untuk mencerdaskan bangsa tidak disertakan agenda untuk kepentingan individu dan kelompok. Karena pada dasarnya film termaksud dalam media massa yang mempunyai pengaruh cukup besar di masyarakat.

\section{UCAPAN TERIMA KASIH}

Penulis mengucapkan terima kasih dan penghargaan yang setinggi-tingginya kepada reviewer dan editor yang telah menelaah dan mereview artikel ini. Terima kasih juga penulis hatur kepada tim redaksi Jurnal Avant Garde yang telah memberi masukan dan arahan hingga artikel ini diterima dan diterbitkan.

\section{DAFTAR PUSTAKA}

Bagong, Suyanto. Sutinah. (2005). Metode Penelitian Sosial Berbagai Alternatif Pendekatan. Jakarta: Kencana Prenada Media Group.

Desi Kristianigrum, Maria. Konstruksi Sosok Perjuangan Mgr. Albertus Soegijapranata, S.J dalam Film Soegija. Jurnal Komunikasi Universitas Semarang. 2010.

Handayani, Fitriana. Representasi Pluralisme Agama dalam Majalah Madina (Analisis Semiotika Charles Saunders Peirce). Jurnal Universitas Padjajaran Bandung. 2010.

Hidayati, Nani Damayanti dan Nurul, Bahasa Indonesia. (2006). Bandung: Grafindo.

Hoed, Benny H. (2014). Semiotika dan Dinamika Sosial Budaya. Depok: Komunitas Bambu. John Fiske,1(1987). Television Culture, London: Methuen \& Co. Ltd.

Kriyantono, Racmat, (2006). Teknis Praktis Riset Komunikasi. Jakarta: Kencana Prenada Media Group.

Poespowardo, Seran. (2016). Teori-teori Kritis. Jakarta: PT. Kompas Media Nusantara

Pratista, Himawan. (2008). Memahami Film. Yogyakarta: Homerian Pustaka.

Retno Listyarti dan Setiadi, (2006). Pendidikan Kewarganegaraan untuk SMK dan MAK Kelas $X$. Jakarta: Erlangga.

Sugihastuti, Suharto. (2002). Kritik Sastra Feminis: Teori dan Aplikasinya. Yogyakarta: Pustaka Pelajar.

Sobur, Alex. (2009). Analisis Teks Media, Suatu Pengantar Untuk Analisis Wacana, Analisis Semiotik, dan Analisis Framing. Bandung: Remaja Rosdakarya.

Sobur, Alex. (2016). Semiotika Komunikasi. Bandung: PT. Remaja Rosdakarya. 
Xaverius Diaz, Fransiskus. Pengadeganan Tokoh Soegija Dalam Film Soegija Karya Garin Nugroho. Jurnal Fakultas Seni Rupa dan Desain Institut Seni Indonesia Surakarta. 2017. 